\title{
Evaluation of Employee Performance to Maintain its Existence in the Business World
}

\author{
Helmia Cipta Rohmawa*1, Zulfiati Syahrial², Jeni Sista Siregar ${ }^{3}$, Jarudin ${ }^{4}$ \\ ${ }^{1}$ Vocational Educational Technology, Universitas Negeri Jakarta, DKI Jaya Jakarta, 13220, Indonesia. \\ E-mail: helmiacipta@gmail.com \\ ${ }^{2}$ Fakultas Pascasarjana, Universitas Negeri Jakarta, East Jakarta, DKI Jaya Jakarta, 13220, Indonesia. \\ ${ }^{3}$ Vacational Educational Technology, Universitas Negeri Jakarta, DKI Jaya Jakarta, 13220, Indonesia. \\ ${ }^{4}$ Information Technology, STMIK Bina Sarana Global, Tangerang, Banten, 15114, Indonesia. Email: \\ jarudinw@gmail.com
}

*Corresponding Author: Helmia Cipta Rohmawa, Vocational Educational Technology, Universitas Negeri Jakarta, East Jakarta, DKI Jaya Jakarta, 13220, Indonesia, helmiacipta@gmail.com

\begin{abstract}
This study aims to evaluate the performance of employees towards the sale of products and services in serving the needs of customers, especially the bride and groom. The sampling technique in this study is purposive sampling, which is by considering certain criteria that have been made for the object following the study. So the sample in this study is the company director (one person), customer service in the field of products and services (two people), managers/supervisors in the field of products and services (two people) and beauticians in the field of products and services (two people). In carrying out this evaluation, researchers used a qualitative approach and also used quantitative data to support the implementation of data analysis. The results of the evaluation of internal factors, there are three measurements used as benchmarks, namely: (1) the innovation process; (2) operation process; and (3) After-sales service process. The results of the evaluation of external factors, there are three measurements used as benchmarks, namely: (1) Customer care; (2) Professionalism and (3) Communication climate. The results of the study propose to improve employee performance by providing intensive targets that can be completed according to timed.
\end{abstract}

Keywords: Employee Performance Evaluation; Business Existence; Beauty Clinic

\section{INTRODUCTION}

Problems in employee performance can be seen from the presence of employees who leave the office during working hours for personal gain. Lack of employee discipline from initial observations in the field shows that at PT. $X$ there are still some employees who arrive not on time, which causes delays in work that should have been completed right on the same day. Besides, there are also employees unable to do the work according to predetermined targets or have double jobs at the same time. When an employee can not finish the job properly and rely on the tasks assigned to other employees, this shows that the performance of employees at PT. $X$ is not optimal. 
PT. X, which operates in the studio of beauty salons and beauty clinics, is one of the companies that offer a variety of services that the bride and groom need to prepare for a wedding, including a makeup package complete, a modern makeup package, a Javanese makeup package, and a ceremony, and equipment rental. tools to complete the traditional ceremony and are equipped with a facial treatment package for the bride and groom under the supervision of a dermatologist who is certainly not all places provide this package.

In this globalization era, the competition of companies in an industry is getting tougher to meet increasingly complex human needs. Companies are required to provide the best service to consumers and business partners. This causes human resources are required to show the best performance so the company can compete with its competitors. Human resources have a very vital role in a company. Every company wants employees who have performed according to the standards set by the company before or even exceed it. This study generally aims to evaluate the performance of employees towards the sale of products and services at PT. $X$ in serving the needs of customers, especially the bride and groom.

\section{LITERATURE REVIEW}

Evaluation is an ongoing activity through established procedures based on the scientific methods of Stuflebeam and Shikfield, said the definition of evaluation is: "evaluation is the systematic assessment of an object's merit, worth, probity, feasibility, safety, significance and or equity" (Stufflebeam \& Shinkfield, 2007). This understanding explains that evaluation is a systematic assessment of an advantage, worthiness, honesty, security, significance and / or fairness of an object. So according to Stufflebeam and Shikfield the evaluation can be concluded as a series of measurement steps arranged in a planned manner towards an object/program to find out all its strengths, feasibility, truthfulness and security to assist in making a decision, take responsibility and increase understanding.

Evaluation is probably the most important activity that has allowed us to evolve, develop, improve things, and survive in an ever-changing environment. Every time we try something new a farming method, a manufacturing process, a medical treatment, a social change program, a new management team, policy or strategy, or a new information system - it is important to consider its value. " (Jane, 2005). Meanwhile, according to Mardapi, Evaluation is one of a series of activities in improving the quality, performance, or productivity of an institution in implementing its program (Mardapi, 2012). Evaluation is an activity that has been arranged in detail which is useful to improve the quality, performance or productivity of an institution/agency to obtain a conclusion. Evaluation is seen by Wholey as an important process for stimulating effective management (Wholey et al., 2010). However, in contrast to Stufflebeam, Wholey links evaluation more with management benefits (especially short-term profits), instrumental and usability(Stufflebeam \& Shinkfield, 2007).

Performance is the willingness of a person or group of people to carry out an activity and perfect it according to their responsibilities with the expected results. Performance according to Wilson is the result of work achieved by someone based on job requirements. A job has certain requirements to be carried out in achieving goals which are also called job standards (Wilson, 2012). If the work results exceed the work standards can be said to be a good performance. Conversely, if the work achieved is lower than the work standard, then the performance is low or not good.

Performance evaluation according to Noe (2010) that performance is a process in which an organization gets information about how well an employee is doing his work (Noe, 2010). Every individual has differences in attitudes, behavior, education, abilities, and knowledge. According to Surya, a formal evaluation of performance is used to evaluate employee performance periodically determined by the organization (Surya, 2014). Performance evaluation can be carried out in stages of evaluation to improve performance in the future. According to Sentono, in evaluating performance that needs to be considered include the performance dimension, which includes the results of skills, achievements, and attitudes from humans. A person's attitude can include integrity, loyalty, personality, obedience (Sentono, 1999). In this study, the purpose of the performance is referring to the definition of actions, achievements, and skills 
shown by someone in doing work in an organization/company, so that it can be assessed regarding its quality, whether its performance is low, medium or high.

According to Ebert and Griffin performance evaluation helps in determining salary and promotion of positions, this evaluation must be carried out fairly and without discrimination (Elbert \& Grififin, 2002). Individual performance evaluation results can be utilized for many uses, including 1) Improved performance; 2) HR Development; 3) Providing compensation; 4) Productivity improvement program; 5) staffing program; 6) Avoiding discrimination. The evaluation of individual employees 'performance and a clear definition of results are the hugest parameters of all the other activities of the Management By Object method which we took in the study to raise employees' effectiveness in the organization (Islami et al., 2018). The success and development opportunities of personal staff should be assessed according to their potential and contribution to the organization's values and business results. According to him, high performing individuals within the organization should be evaluated by effective performance and competence assessment systems. After that, successful results can be obtained by differentiating the ones with higher performance and applying flexible and creative recognition and reward systems (Vural et al., 2012).

\section{METHODOLOGY/MATERIALS}

The method used in this research is case studies. According to Jailani, case studies are a type of approach in research where the review of one case is carried out intensively, deeply, in detail, and comprehensively. The case study approach is essentially focused on the case (case). These cases can be obtained from unique cases, specific contexts, issues that are developing, cultural, natural, holistic, phenomena and others. The case itself is a complex whole operating in several contexts, including physical, economic, ethical (Jailani, 2013).

Case study research methods about evaluating performance have several methods that can be applied by companies in conducting performance appraisals on their employees. The sampling technique in this study is purposive sampling, which is by considering certain criteria that have been made against objects that are following the study (Sugiyono, 2016). The sample in this study is the company director (one person), customer service in the field of products and services (two people), managers/supervisors in the field of products and services (two people) and beauticians in the field of products and services (two people). In carrying out this evaluation, researchers used a qualitative approach and also used quantitative data to support the implementation of

\section{RESULTS AND FINDINGS}

\section{RESULTS}

Performance appraisal is a process used by the leadership to determine whether an employee is doing his job following his duties and responsibilities and as a means to measure the productivity of the company that is running. PT. $X$ conducts an assessment of its performance so far based only on its financial data which is used as a benchmark to determine the level of productivity of companies affected by short-term profits. The profit that has been obtained by the company every year is considered to be able to maintain the company in business competition.

However, assessing the results of company performance that only assesses from the aspect of financial data alone is not enough to maintain and advance the company. Beyond the financial aspect, other factors can encourage the company to achieve optimal company success in the long run. These factors can influence such factors as customer satisfaction, employee productivity, the effectiveness of production activities, promotional activities are undertaken and so on. To be able to assess all important factors in the company can be done with a Balanced Scorecard analysis. Based on this matter, this 
research was conducted to provide a new alternative for the company to measure its performance using the Balanced Scorecard (BSC) approach.

\section{Financial Perspective}

The Liquidity Ratio describes the company's ability to settle its short-term obligations. These ratios can be calculated through sources of information about working capital namely current assets and current debt. Liquidity Ratio consists of Current Ratio from 2017 to 2019 which is presented in table 1 below:

Table1: Current Ratio (Neraca, 2019)

\begin{tabular}{llll}
\hline Years & Current Asset & Current Liabilities & Current Ratio \\
\hline 2017 & Rp, 630,067,827 & Rp 37,327,984 & $16.88 \%$ \\
2018 & Rp, 734.515.121 & Rp 55,992,800 & $13.12 \%$ \\
2019 & Rp. 732.500.120 & Rp. 69.500 .500 & $10.54 \%$ \\
\hline
\end{tabular}

Based on the above calculation, the company's ability to repay debt using the current ratio is quite good. In 2017, a current ratio of $16.88 \%$ showed that the current debt of Rp 1.00 was guaranteed with current assets of 16.88 times. Whereas in 2018 PT X's current ratio of $13.12 \%$ shows that the current debt of Rp 1 is guaranteed with current assets of 13.12 times. In 2019 , the current ratio of $10.54 \%$ shows that the current debt of Rp 1 is guaranteed with current assets of 10.54 times. Below is a diagram of the calculation of the current ratio from 2017 to 2019.

\section{Customer Perspective}

Customers are those who use the products or services produced by the company. The strategy required by the company to achieve company success is to maintain the quality and quality of the products produced, carry out good promotional activities to customers, set efficient prices, provide maximum service to customers. Customer satisfaction with the products produced by the company and the services provided will determine the company's success. From the customer's perspective, it can be measured by Customer Core Measurement, Customer Value Proportion, and analyzing questionnaires.

\section{(1). Customer Core Measurement}

The level of market share, customer retention, customer acquisition, and the level of customer satisfaction are the benchmarks in performance measurement based on Customer Core Measurement. PT $X$ provides bridal makeup and beauty products. PT. $X$ has been serving bridal makeup and selling beauty products to several customers. the company has a package of products and services in beauty clinics and beauty salons including bridal makeup studios. At this beauty clinic, customers can directly consult a dermatologist and will be given advice/actions that are appropriate to the problems of the customer's facial skin. Supported by clinical equipment that is quite complete as well as modern and a variety of products for facial care.

\section{(2) Customer Value Proposition}

There are three benchmarks used in measuring Customer Value Proposition, namely product or service attributes, customer relationships, and the last is the image and reputation of the products or services provided by the company. 


\section{a. Measurement of product and service attributes}

In measuring the attributes of products and services the same as measuring customer satisfaction. Based on the results of interviews with key customers of PT.X that customers are satisfied with the skin and facial care services as well as the products used. Customers consider that the services and products they produce are a lot of fun, because in terms of results that are comfortable and in line with expectations. The services provided fulfill what customers want.

\section{b. Relationship with customers}

Relations with customers is one of the keys that are very important to keep customers. Establishing a good relationship with customers can be done by providing good service and increasing customer satisfaction of course with quality products and quality. Relationship with customers is a means used to measure customer satisfaction with the services and products offered. The relationship created between the company and its customers is very good. Proven the company's main customers have for years been loyal customers of the company. It happened because the customer felt satisfied and following the quality of the products and services provided by PT. X. It can be interpreted that PT. X can keep its customers using the company's products and services for a long time.

\section{c. Image and Reputation}

A good image and reputation will provide goodwill for the company. Services provided by the company to customers in the use of services and when ordering beauty products greatly affect the product transaction process that will be used. At this time, the company provides after-sales service that allows product returns or returns on items that don't fit the grill but of the many products produced, only a few items are returned, due to a skin allergy. The results of beauty products PT. $X$ has a good reputation among its competitors because the director is a specialist skin and beauty specialist and is controlled directly by the director in the service of the customer, so the customer feels satisfied.

\section{Business and Internal Process Perspectives}

Internal business process perspective refers to the company's activities, to assess the company's performance so far in carrying out its activities, whether it is efficient and effective. From the perspective of internal business processes, three measurements will be used as benchmarks, namely: (1) the innovation process; (2) operation process; (3) After-sales service process. The following are the results of research conducted to assess the performance of PT. X based on all three benchmarks.

\section{(1) Innovation Process}

Viewed from the side of the innovation process, PT X is currently gradually making efforts to develop product innovation because the company is very concerned with what its customers want. PT X always provides services and beauty products based on the wishes and orders of its main customers. With the emergence of bridal make-up trends and skin and face treatments that are increasingly fast developing, PT $X$ also does not want to be left behind, one example of the innovations developed by the company is the use of face whitening that is safe for health and harmless for skin exposed to sunlight. PT $X$ also manufactures beauty products that are safe for health. 


\section{(2) Operation Process}

The operation process that has been carried out is very dependent on the expertise of each cosmetologist and dermatologist in providing bridal makeup services and for skin and facial care to provide services that meet customer expectations. As for the process of beauty products handled by experts in the field of chemicals and dermatologists, almost all are handled by experts in their respective fields. To be more accurate, PT X's productivity level is calculated.

The following is the calculation of PT X's productivity in 2017-2019 which is presented in the form of table 2 below.

Table 2: Productivity PT X years 2017-2019

\begin{tabular}{llll}
\hline Years & Total Pendapatan & Cost of goods sold & Productivity \\
\hline 2017 & Rp. 522.385 .250 & Rp. 165.762 .530 & 3.13 \\
2018 & Rp. 627.832 .544 & Rp. 229.097.256 & 2.74 \\
2019 & Rp. 533.219.540 & Rp. 239.393.000 & 2.23 \\
\hline
\end{tabular}

Based on the calculation of productivity in 2017, 2018 and 2019, there was a decrease in 2017 to 2018 of $0.39 \%$, while from 2018 to 2019 there was a decrease of $0.51 \%$. This decline will affect the level of financial performance at PT X.

\section{(3) After Sales Service (Post Sales)}

After-sales services, activities related to after-sales services are services provided to customers after making a transaction process for the purchase of products or services carried out by customers. In this case, the company usually provides after-sales service by allowing the return of goods or returns if there is a defect or does not match the customer's skin on the beauty product that has been purchased. However, product defects are almost uncommon because any damage will be sorted out immediately and not marketed. PT X always strives to meet the needs of customers by striving to improve the quality of products produced, adjusting production results following customer demand, improving service quality by treating customers well.

\section{Learning and Growth Perspective}

In measuring company performance, it is not only customers and internal business processes that have a significant share in non-financial performance, but the performance of employees also contributes to achieving effective performance. This fourth perspective is a controlling factor and driving the objectives of the previous perspective is achieved. The more advanced the employee's career certainly will be more supportive to improve company performance, because employees have the ability and skills that are getting better. There are three main categories of employee learning and growth measures, namely: Employee capability; motivation, empowerment, alignment, and information system capabilities.

Based on the results of PT X performance measurements using the Balanced Scorecard, it is known that customer and worker satisfaction with PT X is good enough. However, some things become customer dissatisfaction that comes from the number of product requests that can not be fulfilled, prices are relatively higher compared to its competitors, and promotional activities are still not running. The different skills, satisfaction, and motivation of each worker have an impact on the services that can be produced by different workers. This must be quickly corrected by the company so that the company's targets can be achieved. From the results of measurements with the Balanced Scorecard also found a decrease in the current ratio, which is a decrease in the ability to repay debt using its current assets. From the problems faced by the company, the production target that was not achieved was due to the productivity of less stable workers, caused by a large number of double job workers and also the dependence on the main customers not to explore new customers either through promotions or utilizing 
social media which is currently developing very rapidly. Besides, differences in salary and bonus receipts cause workers to lack motivation so productivity is not optimal.

\section{FINDING}

Performance is basically what is done and what is not done by an employee (Osibanjo \& Adeniji, 2016). For performance, criteria refer to the quality of put out, the quantity of put out, the deadline of put out, the presence of work, and the nature of cooperation. Bhattacharya et. al (2015) said that assessment criteria should reflect employee contributions to work (Bhattacharya et al., 2015). The frequency with which performance appraisals are carried out depends on practical considerations and also the type of employee being evaluated (Wahjono, 2016). In general, performance appraisals are carried out between six months to once a year. With high-tech companies, the performance evaluation distance between periods will be shorter, which is around three or four months. In the current business climate, companies need to carry out more frequent monitoring, because the changes that occur cause employees to have to revisit the company's goals and their roles during the assessment period to consider the changes that need to be made. However, some experts believe the frequency of performance appraisal is based on the period of the job. The goodness of this method is that work performance is directly measured and recorded when the employee finishes doing his work. The weakness of this method is the possibility of the frequency of assessment is very large if the work carried out only requires a short completion time.

Based on the results of interviews with the director of PT.X that all employees can complete work assignments $100 \%$ satisfactorily, but still, need guidance from leaders in their respective fields. PT.X is engaged in bridal makeup and skin and face care services, if the work is not completed $100 \%$ then this company will not last for a long time as it is now for almost 20 years the company exists in maintaining its business. In a traditional appraisal system, an employee's performance is only assessed by superiors and based on financial reports only. This system contains weaknesses because the boss is not necessarily the person who best understands the performance of his subordinates and from the increase in income because there are still other factors that can affect employee performance. Perhaps those who know better about an employee's performance are people who work with these employees such as coworkers, subordinates, customers, and even themselves. Therefore there is a need for a 360-degree performance evaluation system. Other sources that can be used are colleagues, subordinates, customers, themselves, workers, and others. An increase in the level of confidence in the performance appraisal occurs when there is more than one assessor.

This opinion is supported by Vardarlier (2016), several potential sources for performance measurement are supervisors, peers, self-appraisal, sub-ordinate computer, customers, job (Vardarlier, 2016). Regardless of the extent of the possibility of valuation coming from various sources to obtain more objective information about the performance of an employee, an appraiser must have certain qualifications in conducting an assessment. Gathering assessments from various sources can add to the reliability of the assessment results and will also attract more attention from the employees being assessed. This kind of assessment process is known as a 360-degree assessment, where individuals get feedback from subordinates, coworkers, supervisors, themselves and internal and external customers.

Innovation is widely recognized as an important competitive advantage for companies that want to remain competitive and survive and grow (Tohidi \& Jabbari, 2012). the importance of innovation is fully realized by most companies to produce satisfying profits or competitive advantages. The process of innovation from idea to product is a rigorous process for managing innovation, including a disciplined step-by-step approval process combined with routine measurement of each factor starting from the time and money spent on the success of new products in the market (Tohidi et al., 2010). Innovation is widely recognized as an important competitive advantage for companies that want to remain competitive and survive and grow (Tohidi \& Jabbari, 2012). the importance of innovation is fully realized by most companies to produce satisfactory profits or competitive advantage. The process of innovation from idea 
to product is a rigorous process for managing innovation, including a disciplined step-by-step approval process combined with routine measurement of each factor starting from the time and money spent on the success of new products in the market(Tohidi \& Jabbari, 2012).

The high and low performance of an employee is certainly determined by the factors that influence it directly or indirectly. Internal factors are factors that originate from within an individual/person. The performance of each person is influenced by many factors that can be classified into 3 groups, namely the individual competency of the person concerned, organizational support and management support. Individual competence is the ability and skills to do work (Islami et al., 2018). The ability and work skills of each person are influenced by the physical and mental health of the individual concerned, education, accumulation of training, and work experience (Hanafi \& Ibrahim, 2018). The physical and mental health of individuals makes people able and endure working long and hard work. Conversely, workers who are malnourished will be weak and tired, and unable to do heavy work. Likewise, psychiatric disorders due to frustration and socioeconomic problems make the person concerned inconsistent and not concentrated doing work. Education and training are part of the human investment (Giziene et al., 2015). The longer time a person takes for education and training, the higher the ability or competence to do work, and thus the higher the performance.

External factors are factors that affect the performance of someone who comes from the environment. Such as the behavior, attitudes, and actions of coworkers, subordinates or leaders, work facilities, and customer organization climate, and after-sales. According to Arvey \& Murphy the success or failure of the performance achieved by an organization is influenced by the level of performance of employees, both individually and in groups, assuming that the better the performance of employees, the better expected organizational performance will be(Arvey \& Murphy, 2018). Company performance and the performance of each person also depends greatly on managerial skills, both by building work systems and industrial relations that are safe and harmonious, as well as by developing employee competencies, competency development can be done with training, as well as fostering motivation and mobilization of all employees to work optimally (Shet et al., 2019).

Training is briefly defined as an activity to improve current performance and future performance (Motlokoa, 2018). Whereas management development is a process of how management gains experience, expertise, and attitudes to become or achieve success as leaders in organizations (Sherwani, 2014). Therefore, the development activities are aimed at helping employees to be able to handle the answers in the future, by paying attention to the tasks and obligations that are faced now.

Based on the results of the evaluation of PT.X nuance has not yet been created which results in the form of appreciation and recognition as a unity of the working part of the company. The existence of forms of appreciation, whether in the form of praise, recognition or correction of work which is one way how the form of company recognition of its employees. Because the communication that has been established is a formality, the attitude of appreciation has not been seen clearly at PT. X creates a climate of comfort and high enthusiasm for work. Not only that, but the existence of a form of appreciation is also a form of means of how the fabric of communication between superiors and subordinates can be formed outside the usual structural communication. As Callagher \& Smith (2017) argues, a dynamic climate needs to be built in the form of an attractive perception of the organization over a longer period, one of which is an attitude of appreciation for each task generated by employees(Callagher \& Smith, 2017).

\section{CONCLUSION}

Based on the results of the evaluation and discussion, then conclusions can be drawn on all aspects of the evaluation which includes evaluation of internal and external factors that affect employee performance. In detail can be described, as follows: 
Internal Factors Affecting Performance

The results of the evaluation of internal factors, there are three measurements used as benchmarks, namely: (1) the innovation process; (2) operation process; and (3) After-sales service process.

\section{External factors Affecting Performance}

The results of the evaluation of external factors, there are three measurements used as benchmarks, namely: (1) Customer care; (2) Professionalism and (3) Communication climate.

After the conclusion of the research, there are several recommendations submitted by researchers, namely: (a) The management should not focus on the main customer but must have an innovation in the strategy of capturing new customers; (b) Management must follow developments in information technology by utilizing social media to increase promotion and capture new customers, and (c) Management must pay attention to the welfare of its employees by including the BPJS program to support government programs.

\section{Reference:}

Arvey, R. D., \& Murphy, K. R. (2018). Performance evaluation in work settings. Annual Review of Psychology, 49, 141-68. https://doi.org/10.1146/annurev.psych.49.1.141

Bhattacharya, M., Gibson, D. E., \& Doty, D. H. (2015). The Effects of Flexibility in Employee Skills, Employee Behaviors, and Human Resource Practices on Firm Performance The Effects of Flexibility in Employee Skills, Employee Behaviors, and Human Resource Practices on Firm Performance + . Journal of Management, 31(August), 1-9. https://doi.org/10.1177/0149206304272347

Callagher, L., \& Smith, P. (2017). Innovation awards: reward, recognition, and RITUAL. International Journal of Innovation Management, 21(5). https://doi.org/10.1142/S1363919617400060

Elbert, \& Griffin. (2002). Business Introduction, Tenth Edition. Erlangga.

Giziene, V., Simanaviciene, Z., \& Palekiene, O. (2015). Evaluation of Investment in Human Capital Economical Effectiveness Evaluation of Investment in Human Capital Economical Effectiveness. Nzinerine Ekonomika-Engineering Economics, 23(2), 106-116 Evaluation. https://doi.org/10.5755/j01.ee.23.2.1541

Hanafi, H. M., \& Ibrahim, S. B. (2018). Impact of Employee Skills on Service Performance. International Journal of Science and Research (IJSR, 7(12), 587-600. https://doi.org/10.21275/ART20193416

Islami, X., Mulolli, E., \& Mustafa, N. (2018). The Effect of Industrial and Internal Factors on the Firm 's Performance The Effect of Industrial and Internal Factors on the Firm 's Performance. AUDCE, 14(5), 154-168.

Jailani, M. S. (2013). Journal of Variative Qualitative Research (Ethnography, Phenomenology, Grounded Theory and Case studies). Remaja Rosda Karya.

Jane, D. E. (2005). Evaluation Methodology Basics. SAGE Publications Ltd.

Mardapi, D. (2012). Measurement of Training Assessment and Evaluation. Nuha Medika.

Motlokoa, M. E. (2018). The Impact of Training on Employees ' Performance : The Case of Banking Sector in Lesotho. International Journal of Human Resource Studies, 8(2), 16-46. https://doi.org/10.5296/ijhrs.v8i2.12812

Noe, et al. (2010). Human Resource Management. The McGraw-Hill Companies, International.

Osibanjo, O. A., \& Adeniji, A. (2016). Human Resource Management : Theory and Practice Part I Overview of Human Resource Management. Overview of Human Resource Management, August, 1-35.

Sentono, S. P. (1999). Human Resource Management (Employee Performance Policy), Tips for building a Competitive Organization ahead of World Free Trade. BPFE. 
Shet, S. V., Patil, S. V., \& Chandawarkar, M. R. (2019). Competency-based superior performance and organizational effectiveness. International Journal of Productivity and Performance Management, 68(4), 753-773. https://doi.org/10.1108/IJPPM-03-2018-0128

Stufflebeam, \& Shinkfield. (2007). Evaluation Theory, Model \& Applications (First). John Wiley\&Sons, inc.

Sugiyono. (2016). Qualitative, Quantitative and R\&D Research Methods. Alfabeta.

Surya, D. (2014). Performance Management, Philosophy, theory, and application. Pustaka pelajar.

Tohidi, H., \& Jabbari, M. M. (2012). CRM as a Marketing Attitude Based on Customer's Information. Procedia Technology, 1, 565-569. https://doi.org/10.1016/j.protcy.2012.02.123

Tohidi, H., Jafari, A., \& Afshar, A. A. (2010). Strategic planning in Iranian educational organizations. Procedia - Social and Behavioral Sciences, 2(2), 3904-3908.

https://doi.org/10.1016/j.sbspro.2010.03.613

Vardarlıer, P. (2016). A strategic approach to human resources management during a crisis. Procedia Social and Behavioral Sciences, 235(October), 463-472. https://doi.org/10.1016/j.sbspro.2016.11.057

Vural, Y., Vardarlier, P., \& Aykir, A. (2012). The Effects of Using Talent Management With Performance Evaluation System Over Employee Commitment. Procedia - Social and Behavioral Sciences, 58, 340-349. https://doi.org/10.1016/j.sbspro.2012.09.1009

Wahjono, S. I. (2016). Human Resource Management (Issue September 2015). SalembaEmpat.

Wholey, J. ., Harry, H. P., \& Newcomer, K. E. (2010). Handbook of Critical Program Evaluation. Jossey bass.

Wilson, B. (2012). Human Resource Management. Erlangga. 